\title{
STUDY OF POWER DENSITY TRANSMITTED FROM CELLULAR BASE STATION TOWERS OF NEPAL TELECOM IN BIRATNAGAR SUB-METROPOLITAN CITY
}

\author{
Dinesh Thapa ${ }^{1,2}$, Ram Bharosh Sahu ${ }^{4}$, Prakash Parajuli ${ }^{1,3}$ and Buddha Ram Shah ${ }^{1 *}$ \\ ${ }^{1}$ Physical Science Laboratory, Faculty of Science, Nepal Academy of Science and Technology (NAST), G.P.O.3323, Khumaltar, Lalitpur, Nepal \\ ${ }^{2}$ Department of Physics and Astronomy, Mississippi State University, Mississippi State 39762, USA \\ ${ }^{3}$ Department of Physics and Astronomy, University of Texas at San Antonio, Texas 78249, USA \\ ${ }^{4}$ Department of Physics, Mahendra Morang Adarsha Multiple Campus, Biratnagar, Morang, Nepal \\ *Corresponding author's email: buddharshah25@gmail.com
}

\begin{abstract}
Background: In this present world, human beings are being exposed directly or indirectly to some kind of ionizing and non-ionizing radiations with the development of recent scientific technologies or by natural phenomena. The study of the measurement of power density (PD) or Radio Frequency (RF) radiated from cellular Base Station Towers (BSTs) is seemed to be important in Nepal like other countries because of its various health effects. In this study, the authors measured the PD radiated from mobile base station towers in Biratnagar sub-metropolitan city, Morang. Methods and Methodology: All together 18 BSTs were selected within Biratnagar for the study purpose. Tenmars TM-196 which is a non-ionizing radiation detector was used to measure the power density. The Global Positioning System (GPS), a space-based satellite navigation system was used to locate the Maximum Peak Point (MPP) from the BSTs. Result: The maximum power density (PD) was observed near Jogbani boarder i.e. $3781.0 \mu \mathrm{W} / \mathrm{m}^{2}$ which was $0.63 \%$ of the NTA guidelines. Similarly, the minimum power density was observed near Rani BRT i.e $1549.3 \mu \mathrm{W} / \mathrm{m}^{2}$ which was $0.26 \%$ of the NTA guidelines. Conclusion: From the survey it can be concluded that there is no significant health hazard to the general people due to non-ionizing radiation radiated from Base Station Towers in Biratnagar.
\end{abstract}

Keywords: Non-ionizing radiation; Power density; TM-196; GPS; NTA

\section{Introduction}

Radio Frequency (RF) is a part of non-ionizing electromagnetic radiation characterized by the frequency spectrum of $3 \mathrm{KHz}-300 \mathrm{GHz}$. Over the last decade, with the increase in the use of the wireless technology, there has been significant concern about the harmful effects regarding the exposure of RF radiation (Akbari, 2012). The use of cellular wireless telephones has been increasing rapidly all around the world. Mobile telephone, most widely used wireless technology is based on the extensive network of the different base stations that connects the users through distinct RF signals (NRPB, 2013). The rapid increment in the number of customers for diverse services has led to an increased number of base stations not only around the world (Nahas et al., 2011) but also in urbanized areas of Nepal like Kathmandu valley, Pokhara, Biratnagar, Bharatpur, etc. In the context of Nepal, due to the lack of proper regulations and policies for the placement of cell phone towers, they are placed haphazardly close to the schools, public playgrounds, commercial buildings, hospitals, colleges and terraces of densely populated urban residential areas
(Parajuli et al., 2015). RF energy as an electromagnetic radiation can't be seen, smelt or felt, it can be realized only after the biological disorders caused by it which can be manifested in the next generation also. Hence the public are unwillingly exposed to continuous, low intensity radiations from these towers (Sivani et al., 2011).

The International Agency for Research on Cancer (IARC), part of World Health Organization (WHO) which claims Radiofrequency Electromagnetic Field (RF-EMF) transmitted from cellular BSTs in the form of constant pulsed microwave radiation (Haumann et al.,2002) has been proved as a "possible human carcinogen" Class $2 \mathrm{~B}(\mathrm{Ng}$, 2013) in 2011. Besides cancer, different reports have revealed that continuous exposure to such radiation has been causing other significant health hazard in human beings like genetic disorder, infertility, and malfunction of brain and heart leading to imbalance in blood pressure, fatigue, insomnia, dizziness, lack of concentration, loss of memory, headache, nausea, vomiting, disturbance in gastrointestinal system, etc. (Shah et al., 2015; Nahas et al., 2011; Sivani et al., 2011). The human exposure to electromagnetic 
fields radiated from cellular towers are calculated in terms of Specific Absorption Rate (R) given by (1).

$R=\frac{\sigma\left|E^{2}\right|}{\rho}$

Where, $\sigma$ is the tissue conductivity, $\mathrm{E}$ is the root mean square of intensity of electrical field at the given point and $\rho$ is the mass density of tissue at that point. Specific Absorption Rate is the amount of RF energy absorbed per unit mass per unit time.

To study about RF radiation and its consequences on human beings, and to monitor the radiation level different guidelines, practices and recommendations have been initiated all over the world by government agencies and international organizations. The strength of this electromagnetic field can be studied under three physical quantities; Electric Field Strength (E), Magnetic Field Strength (B), and Power density (PD). Among these quantities, PD, the amount of electromagnetic energy passing through a point per unit area and normal to the direction of flow of energy per sec (Jackson, 2009) has been measured and presented in this study. In Nepal, Nepal Telecommunication Authority (NTA) is the only government organization authorized to work in this field. According to the drive test measurement in different locations of the Kathmandu valley, it proposes the safety guidelines for the Electromagnetic Radiation (EMR) as the occupational limit and general limit on January, 2013 which is the modified guidelines of Federal Communications Commission (FCC) in the frequency range of 300$1500 \mathrm{MHz}$. According to this the Maximum Permissible Exposure limit for general people is $0.6 \mathrm{~W} / \mathrm{m}^{2}$ for $900 \mathrm{MHz}$ frequency (this is $1 / 10^{\text {th }}$ of the FCC guidelines) and $0.1 \mathrm{~W} / \mathrm{m}^{2}$ for the exposure of greater than $1500 \mathrm{MHz}$ (same as FCC guideline) and the occupational limit is 5 times of the above factor (NTA, 2013).

This research work has been conducted in Biratnagar SubMetropolitan city, in 2014 (February-March) dealing with the assessment of the radiation level near BSTs of this area with the analysis of the observed values in reference to the National and International guidelines and radiation norms adopted in different countries thereby comparing the observed results with that of Kathmandu valley (Parajuli et al., 2015; Parajuli, 2014; Pandey, 2014) to address the consciousness of the public towards RF energy. The radiation level near different BSTs within Biratnagar city in all possible direction around the cell phone tower of 18 Base Station Towers (BSTs) of Nepal Telecom (NTC) including the BSTs from dense, medium and least populated area and having different services across the BSTs was measured.

Biratnagar is a sub-metropolitan municipality which holds $58.48 \mathrm{~km}^{2}$ of the total area. Its geographical location is $26^{\circ} 28^{\prime} 60^{\prime \prime} \mathrm{N} 87^{\circ} 16^{\prime} 60^{\prime \prime} \mathrm{E}$. The town is located in Morang district in the Kosi Zone of eastern Nepal. It lies 399km east of the capital Kathmandu, $6 \mathrm{~km}$ north of the border of the Indian state of Bihar at a mean elevation of about $81 \mathrm{~m}$ (265ft.) from the sea level. It has been expected that the result of this work will be helpful for the concerned authorities and researchers for further investigations.

\section{Materials and Methods}

\section{Materials}

Tenmars-TM 196 and GPSMAP 60CSx were used during the survey period.

\section{Tenmars, RF Three Axis Field Strength Meter, TM-196}

Tenmars, TM-196 is a Non-ionizing radiation (NIR) detector device (Fig. 1) detects the radiation of $10 \mathrm{MHz}$ to $8 \mathrm{GHz}$ frequency range. This is a 3-Axis (isotropic) RF field strength meter with three channel measurement sensor produced by Tenmars Electronics Co.Ltd., Taiwan. This requires either a D.C. power supply of $9 \mathrm{~V}$ battery (NEDA 1604 IEC 6F 22 JIS 006P)* 1 with battery life approximately $15 \mathrm{hr}$ or $220 \mathrm{~V}$ A.C. mains. This is based on the principle of electromagnetic induction. In recent days, this device is widely used in the monitoring of the cellular/cordless phone radiation safety level, microwave oven leakage detector, personal living environment EMF safety etc. (Tenmars User Manual).

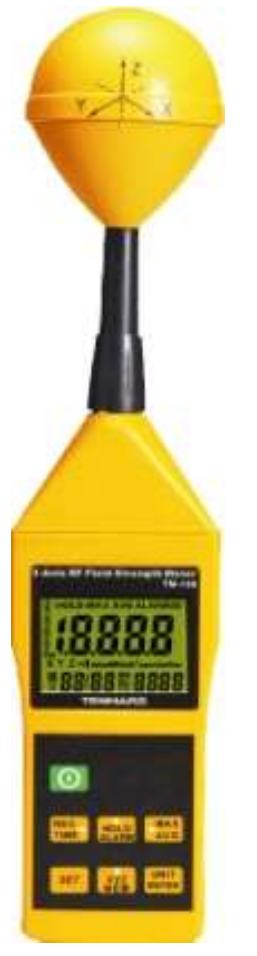

Fig. 1: Tenmars, TM-196

\section{Global Positioning System (GPS)}

GPSMAP 60CSx (Fig. 2), a space based satellite navigation system that provides the information of the location and time in all weather conditions, anywhere on or near the earth. GPS satellite is used to measure the distance of the observation point from the base of the cell phone tower. 


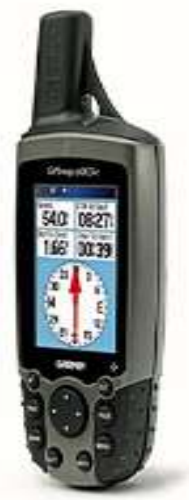

Fig. 2: GPSMAP 60CSx

\section{Measurement Steps}

Before starting survey, information about the different sites BSTs of NTC were obtained from the concerned authorities of the corresponding telecommunication service providers. This study displays data of the mobile phone radiation levels in terms of PD related mainly to the Global System for Mobile Communications (GSM) in Biratnagar, Nepal. Upon arrival to the BSTs, location of the Maximum Peak
Point (MPP) at a particular direction was determined and instantaneous, average and maximum (at the interval of 1 minute and 6 minutes) reading was recorded using Tenmars TM-196 (Parajuli et al., 2015). Also the distance (d) between MPP and BST was measured using GPS. During the observation time, it was found that almost all the observations of $6 \mathrm{~min}$ and $1 \mathrm{~min}$ intervals were within the range of mean $\pm \mathrm{SD}$ of the instantaneous value. Hence, instantaneous values were also recorded for each base station to check the reliability and uniformity of the device and the average and maximum readings were taken for all the BSTs.

Different types of the sectoral antenna structures and towers Green Field (GF) mounted on the ground and Rooftop (RT) mounted on the roof of a building found in the survey are shown in Fig. 3. Observations were taken using 9V battery from 18 towers within Biratnagar from different location (Site) including least populated, medium populated and highly populated area having different services across the site.

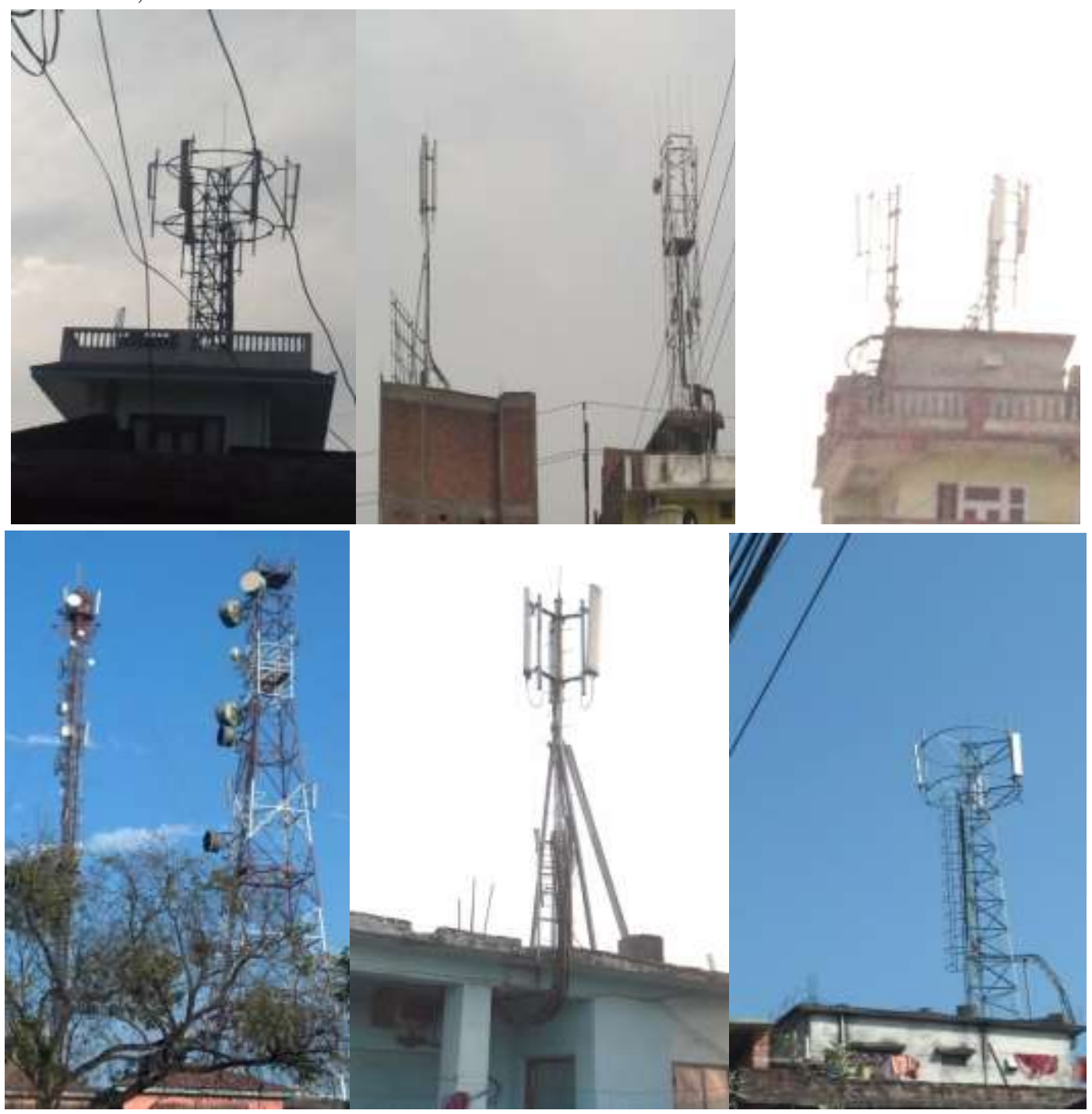

Fig. 3: Different structures of the BSTs observed in the survey 


\section{Mathematical modulation of Power Density (PD)}

In case of single tower in a free space, the PD $\left(\mathrm{w} / \mathrm{m}^{2}\right)$ at a point on the ground at a distance, $\mathrm{d}$ meters from the base of the tower is given by the equation (2)

$P D=\frac{P_{t} A_{t}}{4 \pi R^{2}}$

Where, $P_{t}$ and $A_{t}$ are power and gain from the cellular towers in $\mathrm{dBm}$ and $\mathrm{dB}$ respectively and $\mathrm{R}$ is the distance from the transmission tower to the object at the ground level in meter as shown in Fig. 4. It is to mention that many service providers of cellular network use $\mathrm{P}_{t}$ in the range of $16 \mathrm{dBm}$ to $20 \mathrm{dBm}$

Equation (2) can also be written as,

$P D=\frac{P_{t} A_{t}}{4 \pi\left(d^{2}+h^{2}\right)}$

Where, $\mathrm{d}$ is the distance of the point considered on the ground from the base of the tower and $\mathrm{h}$ is the height of the tower. If we consider the height $\mathrm{h}_{0}$ of the object that may be a house or a human then the PD at the top of the house or at the head of the human is given by (4) as,

$P D=\frac{P_{t} A_{t}}{4 \pi s^{2}}$

Where, $\mathrm{s}=\sqrt{d^{2}+\left(h-h_{0}\right)^{2}}$

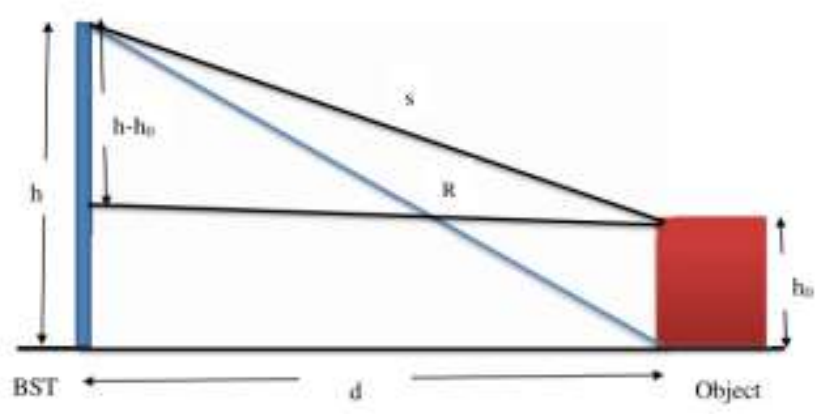

Fig. 4: An object at a distance 'd' from a BST

If there are $n$ number of Base Station Towers at a given location, then the PD at the top of the object with height varying from 0 to $h_{0}$ provided the value of $P_{t}, A_{t}$ and $d$ is given by (5) as,

$P D_{j}=\frac{1}{4 \pi} \sum_{j=1}^{n}\left[\frac{P_{t} A_{t}}{d_{j}^{2}+\left(h_{j}-h_{0}\right)^{2}}\right]$

Also the total PD absorbed by an object of height $\mathrm{h}_{0}$ is given by the integration (6) as,

$\int_{0}^{h_{0}} P D=\frac{P_{t} A_{t}}{4 \pi}\left[\arctan \left(\frac{h}{d}\right)-\arctan \left(\frac{h-h_{0}}{d}\right)\right] \ldots$

\section{Results and Discussion}

From the survey it was found that the maximum power density was observed near Jogbani boarder i.e. $3781.0 \mu \mathrm{W} / \mathrm{m}^{2}$ which was $0.63 \%$ of the NTA guidelines. Similarly, the minimum power density was observed near
Rani BRT i.e $1549.3 \mu \mathrm{W} / \mathrm{m}^{2}$ which was $0.26 \%$ of the NTA guidelines. The area having high value of power density is characterized by the high density of population and more telecommunication services of different service providers like Nepal Telecom (NTC), United Telecom (UTL), NCELL, etc. This confirms that all observed sites are well within the standards of the NTA in terms of the amount of EMFs that the base station is radiating. When the observed Power density is compared to the NTA and other international guidelines, it is found that the radiation level is far below the safe level. Power density recorded in different sites and NTA limit has been presented in Fig. 5 in logarithmic scale in microwatt per square meter $\left(\mu \mathrm{W} / \mathrm{m}^{2}\right)$ unit.

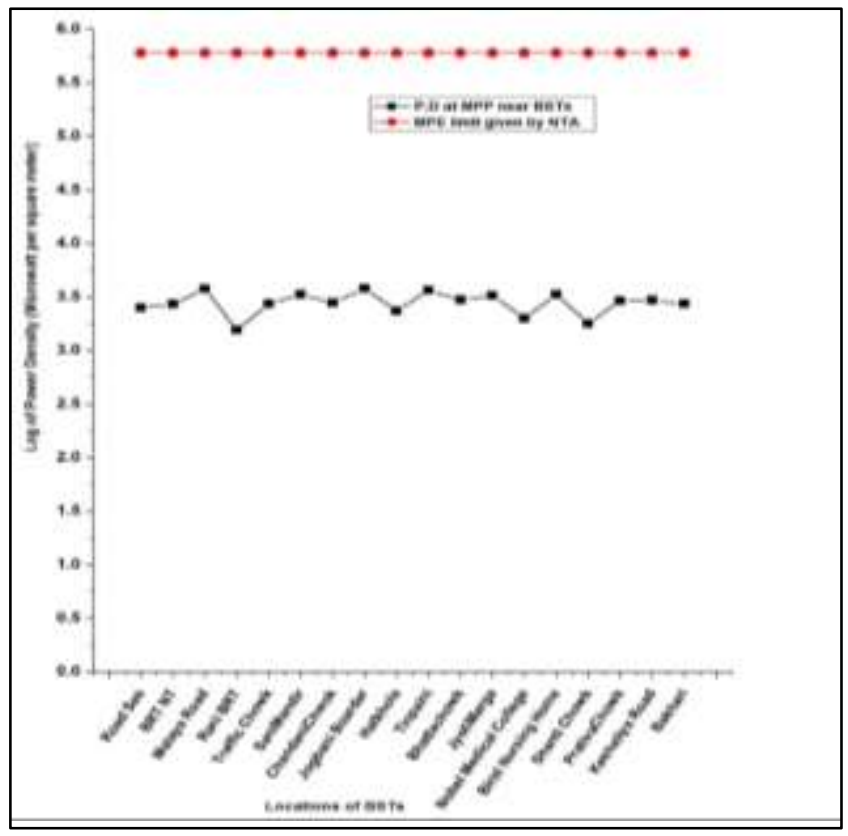

Fig. 5: $\log$ of power density in $\mu \mathrm{W} / \mathrm{m}^{2}$ of different locations and Maximum Permissible Exposure (MPE) limit set by NTA

It is found from many reports that most of the countries in the world have been adopting their own radiation limit and norms which are much more stricter maximum radiation density values compared to the international limits: International Commission on Non-Ionizing Radiation Protection (ICNIRP) (ICNIRP, 1998), the Institute of Electrical and Electronics Engineers (IEEE) (IEEE, 2006), Federal Communication Commission (FCC) (FCC, 1997) etc. like $0.000005 \mathrm{~W} / \mathrm{m}^{2}$ (Australia, New South Wales) (Kumar, 2010). Our neighbouring country India has also adopted ICNIRP limit till September 2013 but, it has been adopting $0.45 \mathrm{~W} / \mathrm{m}^{2}$ limit for general public for the exposure of $900 \mathrm{MHz}$ frequency since September 1, 2013, this is onetenth of the ICNIRP limit (Sivani et al., 2011). As compared to the limit adopted in Australia, this observed value is approximately $756(0.003781 / 0.000005=756.20)$ times greater than the MPE limit adopted here. This clearly 
indicates MPE limit adopted in Nepal is high with respect to some other countries. Also it was mentioned that, four cancer cases were linked to mobile towers radiation installed on facing Vijay apartments (Mumbai's swanky Usha Kiran building) in which the radiated power density level was $0.1 \mathrm{~W} / \mathrm{m}^{2}$ (Kumar, 2010) which is only $16.67 \%$ of the safe limit of Nepal. Thus, the safe limit adopted by Nepal is high with respect to the health hazards and many people are suffering invisibly because of this reason. It is also found that the BSTs are constructed haphazardly without any policies and rule in Nepal.

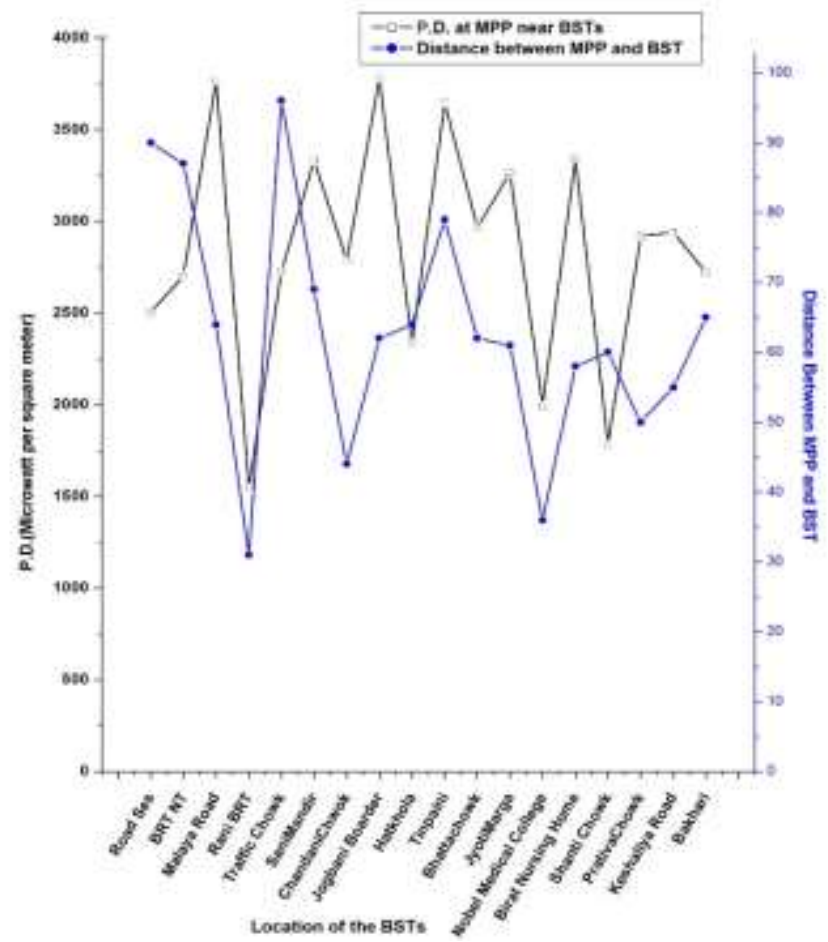

Fig. 6: Power density and distance between MPP and BSTs at different locations.

During the survey time it was found that the PD was highly different in the different directions of the antenna in the same place at different weather condition, in slightly different geographical areas etc. From Fig. 6 (solid line in the graph represents only the connectivity of the points for the better visualization of the observed data) it is seen that, the distance between MPP and BST is highly different. It is obvious that the distance between MPP and BSTs and corresponding Power density at MPP near BST does not show any clear and direct relation, rather it was found that the distance between MPP and BSTs depends on a different parameters like: the antenna height, the beam width of the main beam and tilt angle of the antenna, and also depends upon the geographical condition like height, depth etc. of the observation point and environmental factors like weather, wind etc. ( $\mathrm{Ng}, 2003)$ and $\mathrm{PD}$ at any position depends upon the different factors: site characteristics and general surroundings of each individual site (in terms of geographical nature such as height, depth etc.), vicinity population, site specifications (height, services, type etc. of BST), survey time and weather pattern.

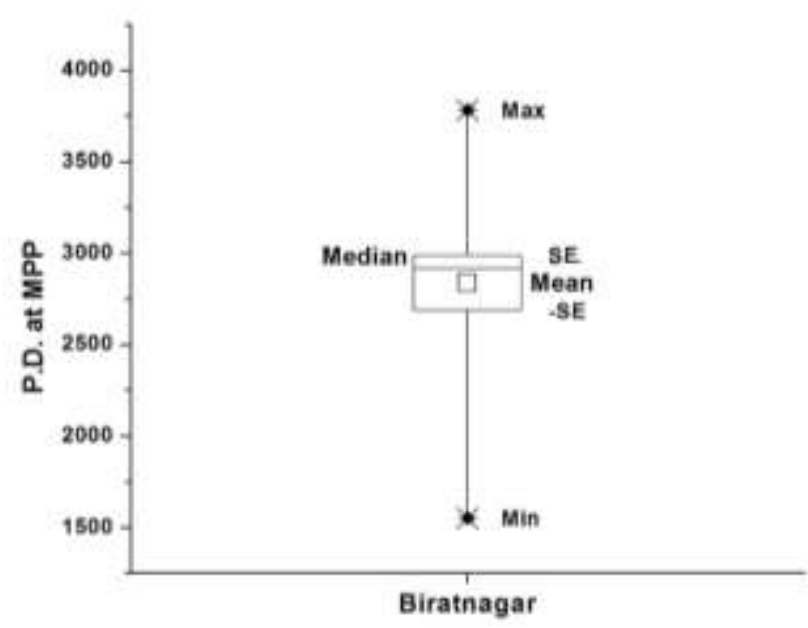

Fig. 7: Box plot of PD at MPP

Fig. 7 shows the box plot of PD at MPP. The comparative study of PD at MPP near BSTs of Biratnagar and that of Kathmandu Valley (Parajuli et al., 2015; Parajuli, 2014; Pandey, 2014) shows that the maximum value of PD near BST at Jogbani boarder of Biratnagar is slightly higher than New Baneshwor area of Kathmandu valley. These areas have high population density and more telecommunication services of different service providers. The study shows the necessity of further investigation in these areas.

\section{Conclusion}

This study concludes that the Power density at MPP near BSTs of different sites within Biratnagar lies well within the safety limit given by NTA and international guidelines but this is high with respect to the health hazards and the radiation norms adopted in some of the countries. Power density level at any point depends upon the different factors: site characteristics and general surroundings of each individual site in terms of geographical nature (height, depth etc.), vicinity population, site specifications (height, services, type etc. of BST), survey time and weather pattern. Power density at MPP does not shows any direct relation with the distance between MPP and BST rather depends on different factors including the number of sources at the point.

\section{Acknowledgement}

The authors are thankful to Faculty of Science, Nepal Academy of Science and Technology (NAST), Khumaltar, Lalitpur for providing financial support to carry out this work. We are thankful to Er. Lav Kumar Dutt of NTC office for providing detailed descriptions about the BSTs located within Biratnagar.The authors Dinesh Thapa and Prakash Parajuli are the awardee of Assistant Research Fellowship (ARF) in NAST.

\section{References}

Akbari A (2012) Electromagnetic Exposure from Wireless Communicational Systems. M.Sc. Thesis. Chalmers University of Technology, Sweden.

Federal Communications Commission (FCC) (1997) Evaluating Compliance with FCC Guidelines for Human Exposure to 
Radiofrequency Electromagnetic Fields, OET Bulletin 65, edition 97-01 (Accessible online at, http://transition.fcc.gov/Bureaus/Engineering Technology/Documents/bulletins /oet65/oet65b.pdf)

Haumann T, Munzenberg U, Maes W and Sierck (2002), HFRadiation Levels of GSM Cellular Phone Towers In Residential Areas, Germany (Accessible online at, http://www.kawarthasafetechnology.org/uploads/1/0/0/8/ 10084439/german_rf_research_article.pdf)

International Commission on Non-Ionizing Radiation Protection (ICNIRP) (1998) ICNIRP Guidelines for Limiting Exposure to Time varying Electric, Magnetic, and Electromagnetic fields (up to $300 \mathrm{GHz}$ ). Health Physics 74(4): 494-522 (Accessible online at, http://www.icnirp.de/documents/emfgdl.pdf)

International Committee on Electromagnetic Safety (IEEE) (2006) IEEE Standard for Safety Levels with Respect to Human Exposure to Radiofrequency Electromagnetic Fields, 3 $\mathrm{kHz}$ to $300 \mathrm{GHz}$, (IEEE C95.1-2005) (Accessible online at, http://rfsafetysolutions.com/PDF\%20 Files/C95.12005 Cover Page.pdf)

Jackson JD (2009) Classical Electrodynamics, Chapter 6, Wiley India Pvt. Ltd., India, third edition, 237-294

Kumar G (2010) Cell Tower Radiation. Electrical Engineering Department, IIT Bombay. (Accessible online at, http://www.ee.iitb.ac.in mwave/GK-cell-tower-radreport-DOT-Dec2010.pdf)

Nahas M and Simsim M T (2011) Safety Measurements of Electromagnetic Fields Radiated from Mobile Base Stations in the Western Region of Saudi Arabia. Wireless Engineering and Technology, 2:221-229.

National Radiological Protection Board (NRPB) (2013) Health Effects from Radiofrequency Electromagnetic Fields - A Report of Independent Advisory Group on Non-ionising Radiation, 14(2) (Accessible online at, http://www.hpa.org.uk/webc/hpaweb_le/hpaweb c/1317133827077)
Nepal Telecommunication Authority (NTA) (2013) Consultation Paper on Guidelines on Health Hazard due to Wireless Communication (Accessible online at, http://www.nta.gov.np/en/component/joomdoc/Consultati on\%20Paper/CP\%202013/Consultation\%20Document.pd f/download)

Ng KH (2003) Non-ionizing Radiations-sources, Biological Effects, Emissions and Exposures. In Proceedings of the International Conference on Non-Ionizing Radiation at UNITEN.

Nyakyi CP, Mrutu SI, Sam A and Anatory J (2013) Safety Zone Determination For Wireless Cellular Tower - A Case Study From Tanzania, International Journal of Research in Engineering and Technology (IJRET), 2(9):194-201. DOI: 10.15623/ijret.2013.0209029

Pandey JP (2014) Measurement of the Electromagnetic Field Radiated from Cell Phone Towers within Kathmandu district. M.Sc. Thesis, Tribhuvan University, Nepal.

Parajuli P (2014) Measurement of the Electromagnetic Field Radiated from Cell Phone Towers within Kathmandu district. M.Sc. Thesis, Tribhuvan University, Nepal.

Parajuli P and et.al. (2015) Study of the Electromagnetic Field Radiated from the Cell Phone Towers within Kathmandu Valley, International Journal of Applied Science and Biotechnology, 3(2): 179-187. DOI: 10.3126/ijasbt.v3i2.12297

Shah BR, Thapa D, Mulmi DD and Dahal KP (2015) Indoor Radon Survey in Nepal Using Passive Technique. Solid State Nuclear Track Detector. International Journal of Clinical and Biomedical Research 1(4): 7-13.

Sivani S and Sudarsanam D (2012) Impacts of radio-frequency electromagnetic field (RF-EMF) from cell phone towers and wireless devices on biosystem and ecosystem-a review. Biology \& Medicine 4(4): 202-216

Tenmars (TM-196), User's Manual, Tenmars Electronics Co. Ltd., Taiwan. 
APPENDIX

Table 1: Power density at MPP near BSTs

\begin{tabular}{|c|c|c|c|c|c|c|}
\hline $\begin{array}{l}\text { Site } \\
\text { Order }\end{array}$ & $\begin{array}{l}\text { Site Description } \\
\text { Type of tower } \\
\text { Height of tower } \\
\text { Population }\end{array}$ & $\begin{array}{l}\text { Date and } \\
\text { time }\end{array}$ & $\begin{array}{l}\text { Services on } \\
\text { site }\end{array}$ & $\begin{array}{l}\text { Horizontal Distance between MPP and } \\
\text { BSTs }(\mathrm{m})\end{array}$ & $\begin{array}{l}\text { Average Power Density at MPP at interval of } 6 \mathrm{~min} \text {. } \\
\left(\mu \mathrm{W} / \mathrm{m}^{2}\right)\end{array}$ & $\begin{array}{l}\text { Percentage of public limit } \\
(\%)\end{array}$ \\
\hline 1 & $\begin{array}{l}\text { Road Ses } \\
\text { RT } \\
\text { 8m } \\
\text { High Population }\end{array}$ & $\begin{array}{l}2014 / 02 / 28 \\
12: 30 \mathrm{pm}\end{array}$ & $\begin{array}{l}\text { GSM } \\
900 / 1800\end{array}$ & $90 \mathrm{~m} \mathrm{~N}$ & 2503.0 & 0.42 \\
\hline 2 & $\begin{array}{l}\text { BRT NT } \\
\text { GF } \\
65 \mathrm{~m} \\
\text { Medium Population }\end{array}$ & $\begin{array}{l}2014 / 02 / 28 \\
2: 45 \mathrm{pm}\end{array}$ & $\begin{array}{l}\text { GSM } \\
900 / 1800\end{array}$ & $87 \mathrm{~m} \mathrm{SW}$ & 2702.0 & 0.45 \\
\hline 3 & $\begin{array}{l}\text { Malaya Road } \\
\text { RF } \\
8 \mathrm{~m} \\
\text { Medium Population }\end{array}$ & $\begin{array}{l}\text { 2014/03/01 } \\
10: 00 \mathrm{am}\end{array}$ & GSM 900 & $64 \mathrm{~m} \mathrm{~W}$ & 3768.0 & 0.63 \\
\hline 4 & $\begin{array}{l}\text { Rani BRT } \\
\text { GF } \\
50 \mathrm{~m} \\
\text { Low Population }\end{array}$ & $\begin{array}{l}2014 / 03 / 01 \\
12: 30 \mathrm{pm}\end{array}$ & $\begin{array}{l}\text { GSM } \\
900 / 1800\end{array}$ & $31 \mathrm{~m} \mathrm{~W}$ & 1549.3 & 0.26 \\
\hline 5 & $\begin{array}{l}\text { Traffic Chowk } \\
\text { RT } \\
8 \mathrm{~m} \\
\text { High Population }\end{array}$ & $\begin{array}{l}2014 / 03 / 01 \\
3: 15 \mathrm{pm}\end{array}$ & $\begin{array}{l}\text { GSM } \\
900 / 1800\end{array}$ & $96 \mathrm{~m} \mathrm{E}$ & 2727.0 & 0.45 \\
\hline 6 & $\begin{array}{l}\text { SaniMandir } \\
\text { RT } \\
5 \mathrm{~m} \\
\text { High Population }\end{array}$ & $\begin{array}{l}\text { 2014/03/01 } \\
5: 30 \mathrm{pm}\end{array}$ & $\begin{array}{l}\text { GSM } \\
900 / 1800\end{array}$ & $69 \mathrm{~m} \mathrm{~N}$ & 3330.0 & 0.56 \\
\hline 7 & $\begin{array}{l}\text { ChandaniChwok } \\
\text { RT } \\
\text { 20m } \\
\text { Low Population }\end{array}$ & $\begin{array}{l}2014 / 03 / 02 \\
10: 00 \mathrm{am}\end{array}$ & GSM 900 & $44 \mathrm{~m} \mathrm{E}$ & 2786.0 & 0.46 \\
\hline 8 & $\begin{array}{l}\text { Jogbani Boarder } \\
\text { RT } \\
8 \mathrm{~m} \\
\text { High Population }\end{array}$ & $\begin{array}{l}2014 / 03 / 02 \\
12: 45 \mathrm{pm}\end{array}$ & GSM 900 & $62 \mathrm{~m} \mathrm{~N}$ & 3781.0 & 0.63 \\
\hline 9 & $\begin{array}{l}\text { Hatkhola } \\
\text { RT } \\
\text { 8m } \\
\text { Low Population }\end{array}$ & $\begin{array}{l}\text { 2014/03/02 } \\
3: 00 \mathrm{pm}\end{array}$ & GSM 900 & $64 \mathrm{~m} \mathrm{~W}$ & 2341.0 & 0.39 \\
\hline
\end{tabular}




\begin{tabular}{|c|c|c|c|c|c|c|}
\hline $\begin{array}{l}\text { Site } \\
\text { Order }\end{array}$ & $\begin{array}{l}\text { Site Description } \\
\text { Type of tower } \\
\text { Height of tower } \\
\text { Population }\end{array}$ & $\begin{array}{l}\text { Date and } \\
\text { time }\end{array}$ & $\begin{array}{l}\text { Services on } \\
\text { site }\end{array}$ & $\begin{array}{l}\text { Horizontal Distance between MPP and } \\
\text { BSTs (m) }\end{array}$ & $\begin{array}{l}\text { Average Power Density at MPP at interval of } 6 \text { min. } \\
\left(\mu \mathrm{W} / \mathrm{m}^{2}\right)\end{array}$ & $\begin{array}{l}\text { Percentage of public limit } \\
(\%)\end{array}$ \\
\hline 10 & $\begin{array}{l}\text { Tinpaini } \\
\text { RT } \\
8 \mathrm{~m} \\
\text { Low Population }\end{array}$ & $\begin{array}{l}2014 / 03 / 03 \\
9: 15 \mathrm{am}\end{array}$ & GSM 900 & $79 \mathrm{~m} \mathrm{~N}$ & 3646.0 & 0.61 \\
\hline 11 & $\begin{array}{l}\text { Bhattachowk } \\
\text { RT } \\
8 \mathrm{~m} \\
\text { Medium Population }\end{array}$ & $\begin{array}{l}2014 / 03 / 03 \\
11: 30 \mathrm{am}\end{array}$ & $\begin{array}{l}\text { GSM } \\
900 / 1800\end{array}$ & $62 \mathrm{~m} \mathrm{E}$ & 2967.0 & 0.49 \\
\hline 12 & $\begin{array}{l}\text { JyotiMarga } \\
\text { RT } \\
8 \mathrm{~m} \\
\text { Medium Population }\end{array}$ & $\begin{array}{l}2014 / 03 / 03 \\
2: 00 \mathrm{pm}\end{array}$ & $\begin{array}{l}\text { GSM } \\
900 / 1800\end{array}$ & $61 \mathrm{~m} \mathrm{NE}$ & 3264.0 & 0.54 \\
\hline 13 & $\begin{array}{l}\text { Nobel Medical } \\
\text { College } \\
\text { RT } \\
8 \mathrm{~m} \\
\text { Low Population }\end{array}$ & $\begin{array}{l}2014 / 03 / 03 \\
4: 30 \mathrm{pm}\end{array}$ & GSM 900 & $36 \mathrm{~m} \mathrm{SE}$ & 1994.2 & 0.33 \\
\hline 14 & $\begin{array}{l}\text { Birat Nursing Home } \\
\text { RT } \\
8 \mathrm{~m} \\
\text { Low Population }\end{array}$ & $\begin{array}{l}2014 / 03 / 04 \\
9: 30 \mathrm{am}\end{array}$ & $\begin{array}{l}\text { GSM } \\
900 / 1800\end{array}$ & $58 \mathrm{~m} \mathrm{SW}$ & 3341.0 & 0.56 \\
\hline 15 & $\begin{array}{l}\text { Shanti Chowk } \\
\text { RT } \\
8 \mathrm{~m} \\
\text { Low Population }\end{array}$ & $\begin{array}{l}2014 / 03 / 04 \\
11: 45 \mathrm{am}\end{array}$ & GSM 900 & $60 \mathrm{~m} \mathrm{E}$ & 1785.0 & 0.29 \\
\hline 16 & $\begin{array}{l}\text { PrativaChowk } \\
\text { RT } \\
8 \mathrm{~m} \\
\text { Low Population }\end{array}$ & $\begin{array}{l}2014 / 03 / 04 \\
3: 00 \mathrm{pm}\end{array}$ & GSM 900 & $50 \mathrm{~m} \mathrm{~S}$ & 2917.0 & 0.49 \\
\hline 17 & $\begin{array}{l}\text { Keshaliya Road } \\
\text { RT } \\
8 \mathrm{~m} \\
\text { High Population }\end{array}$ & $\begin{array}{l}2014 / 03 / 05 \\
11: 00 \mathrm{am}\end{array}$ & GSM 900 & $55 \mathrm{~m} \mathrm{SW}$ & 2941.0 & 0.49 \\
\hline 18 & $\begin{array}{l}\text { Bakhari } \\
\text { RT } \\
8 \mathrm{~m} \\
\text { Medium Population }\end{array}$ & $\begin{array}{l}2014 / 03 / 05 \\
3: 00 \mathrm{pm}\end{array}$ & GSM 900 & $65 \mathrm{~m} \mathrm{SE}$ & 2721.0 & 0.45 \\
\hline
\end{tabular}

